\title{
Issues and Opportunities in Digital Rights Management
}

\author{
Abbas Foroughi, Marvin Albin, and Sharlett Gillard \\ University of Southern Indiana, Evansville, USA
}

aforoughi@usi.edu malbin@usi.edt sqiltard@usi.edtu

\section{Abstract}

In the wake of the Digital Millennium Copyright Act, of 1998, Digital Rights Management systems are beginning to provide copyright protection for digital content which magazine and book publishers, music companies, software and game producers, and business-to-business participants place online. Creators and providers of digital content are now increasingly able to control end users' use of, and accessibility to, their products and stand to gain huge profits from this capability. However, as DRM technologies evolve and develop, so does end user concern about restrictions to their access to, and use of, information. The DRM industry will have to provide a balance between fair compensation for the creators of digital content and the rights of end-users to access and use the information they need.

Keywords: Digital Rights Management, e-Business, copyright protection

\section{Introduction}

E-business has established itself as the marketplace of the future. "According to Forrester Research, the United States is expected to spend \$1.4 trillion dollars online by 2004" (ViaPay, 2000). Consumer demand for digital content, with its lower costs, round the clock convenience, and global accessibility, is expected to bring the market for online books, magazines, music, software, and games to $\$ 275$ billion by 2003 (ContentGuard, 2000).

However, many content providers, such as magazine and book publishers, music companies, and software and game producers have reservations about entering the e-business market. They worry that, if placed on the Internet, their digital eContent will be used, duplicated, and distributed without authorization and compensation. Billing and distributing digital works are seen as additional complications. Also important is the concern for establishing a balance between convenience of access and consumers' trust and confidence in the quality of digital works they acquire (ContentGuard, 2000). Identity, attribution, security, convenience, trust, control, and revenue-all are challenges related to the distribution of digital content on the Internet (Convergent Information Systems Division, National Institute of Standards and Technology, 2001). "If stuff you create can be misappropriated, your incentive for continuing to create valuable intellectual property diminishes significantly," said Tony Henning, senior analyst of virtual asset management at Future Image digital photography specialists (Sanborn, 2000,).

Concern over accessibility to digital content is not limited to the commercial sector. Companies worry about possible misuse of internal information. According to Media DNA's Vernec, "Fortune 2000 com-

Material published as part of these proceedings, either on-line or in print, is copyrighted by Informing Science. Permission to make digital or paper copy of part or all of these works for personal or classroom use is granted without fee provided that the copies are not made or distributed for profit or commercial advantage AND that copies 1) bear this notice in full and 2) give the full citation on the first page. It is permissible to abstract these works so long as credit is given. To copy in all other cases or to republish or to post on a server or to redistribute to lists requires specific permission from the publisher atpublisher@intormingscience.org panies are expanding their intranets and extranets to share digital content with employees, partners, and suppliers. This is content that's not for sale, but must be strictly controlled: business and financial plans, technical specs, schematics, price lists, etc. "(O'Leary, 2001).

Concerns about piracy and the security of digital content have presented a stumbling block to the en- 
try of digital content providers into the world of eBusiness. In 1998, the United States government passed the Digital Millennium Copyright Act (DMCA), which gives copyright protection to creators and providers of digital content and outlaws the creation of devices or products which can circumvent digital watermarking, encryption, and other technologies used to prevent pirating or other forms of copyright infringement (Oliva and Prabakar, 1999). This legislation was an important step toward protecting digital content, but it also created a situation for e-business practitioners in which they must remain updated about copyright law in order to avoid inadvertently taking another's copyrighted material and reducing its value by using it or transmitting it (Oliva and Prabakar, 1999). They must also be aware of their potential exposure and of possible misuse of their online content (O’Brien, 1999).

\section{Digital Rights Management}

The Digital Millennium Copyright Act provides copyright protection for online content, but the actual policing of the World Wide Web -- pursuing and catching those who have disobeyed copyright laws is very difficult and hit and miss, at best (TechTarget Enterprise, 2001). A ruling against Napster's filesharing activities on its website did not come through until early 2001 (Kontzer, 2001). A much better idea is to prevent unlawful use of online content to begin with. An answer to eContent providers' need for accessibility, yet protection of their products and for companies' need to distribute internal information via intranets and extranets is being provided by Digital Rights Management. DRM is defined as "a series of interfaced technologies, from the content producer to the customer, that protects intellectual property rights, provides secure payment, and promotes varied distribution models" (O'Leary, 2001). Digital Rights Management is still a work in progress. Large companies like Intel, Microsoft, and IBM are among the many firms competing to develop the standards, formats, and business models need to make Digital Rights Management effective (O'Leary, 2001). The result will be technologies that ensure the integrity of digital information commerce by securing eContent providers' digital rights through all eBusiness channels and providing a variety of consumer-friendly payment options. At stake is "a vastly enlarged market for digital content, brought about by secure, enhanced distribution models “(O'Leary, 2001).

According to Media DNA's Marketing VP, Larry Vernec, DRM is part of a large commerce system that will have several elements (O'Leary, 2001). First, content encryption must be built into E-Content that serves as a digital lock that prevents unauthorized use of the content, no matter what the format. Second, keys, such as e-payment or passwords, must be developed to unlock the content and allow it to be used. Also needed are clearinghouses, often third-party companies, to track the content and collect payment through electronic cash registers, different types of payment plans, content packaging, distribution options, and subscriptions. Each eContent producer will need to follow a business model that will determine the choices it makes in terms of encryption, keys, and clearinghouse services. The fourth component of the large commerce system is customers, who want ready access to digital content, and must be provided with convenient ways to pay for it and obtain access.

Digital Rights Management Systems provide features such as the following:

- Encryption of content with built-in eBusiness cash registers

- Plug-ins that end-users must download to have access to content

- Keys to unlock encryption for which end-users must pay money or provide an e-mail address

- Access in exchange for personal information from end-users

- Watermarking of video products

- Pay-per-view formats 
- Discounts for regular customers

- Free previews

- Authorization verification

- Usage tracking

- Subscription capabilities

- Print and copy restrictions

- Time limits on access

- Control of content sharing

- Tracking of use of content - is it viewed, printed, copied, or passed on?

- Digital clearinghouses that handle payment and distribution of content
(\$B)

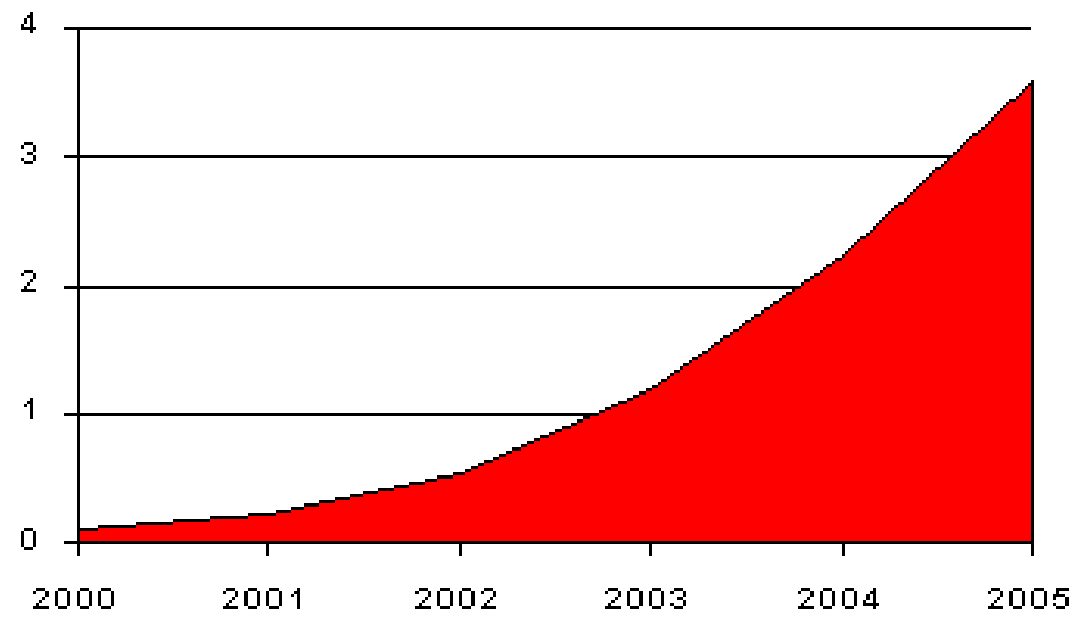

Note: Includes software and software-derived services. Source: Duhl, in IDC\#24891, June 2001

Figure 1: Worldwide Digital Rights Management Market, 2000-2005

As shown in Figure 1, the Worldwide Digital Rights Management Market is expected to rise steadily, reaching approximately $\$ 3.57$ billion dollars by 2005 (Duhl, 2001). The tremendous growth expected from DRM will be driven by four primary market drivers - the demand for intellectual property protection, new revenue opportunities, the protection of privacy and confidentiality, and competing standards (Maclachlan, 2001).

\section{Examples of Existing DRM Systems}

Alchemedia's Clever Content Server 2.0 replaces the media's image tag with its own code. To view the images, users must download the Clever Content Viewer, and may browse images and other media, but cannot copy, paste, print, or take screenshots of those images. A feature called CleverLinks allows content providers to embed links to other media within protected media. Content providers who do not have an inhouse web server have media protection (Dudrow, 2000).

ContentGuard 1.3 is based on XrML, extensible rights markup language, a tag-based language developed at the Xerox Palo Alto Research Center. ContentGuard 1.3 includes a protection toolkit that allows users to set encryption and access parameters, a distribution toolkit for creating storefronts and other means of presenting content to customers, a consumer toolkit for the verification of access terms before issuing content, and a back-office component that tracks usage and license generation (Dudrow, 2001). ContentGuard's RightsEdge service can be used by content providers to try out different business models and marketing methods-- such as pay-per-view distribution models, free previews, or discounts for regular customers - without having to reformat the content itself (Pack, 2001). Users who access ContentGuardenabled documents are routed to a web site where they can obtain a digital "license" to unlock the content. Sometimes they must buy the content as they would in a typical standard eBusiness transaction. The newly acquired content can be sent to other users, but these users must obtain their own licenses before being allowed access to the content (Pack, 2001).

InterTrust DRM allows users to protect text and graphic content such as PDFs and content usage on desktops, television, phones, and portable devices. End users can preview content before purchase, and the software also supports subscriptions and membership sales. InterTrust's DigiBox Container allows access to content only after the owner's access rules have been satisfied (Dudrow, 2001). 
Issues and Opportunities in Digital Rights Management

Vyou.com's Vyoufirst DRM features a Director that allows users to establish content access policies, a Server, and a plug-in that downloads in the background if end-users attempt to access content protected by Vyoufirst (Dudrow, 2001).

Athorit-e, by Phocis, encrypts protected media in a PDF wrapper. To view content, end-users must download a plug-in. Developers can create free previews and alter prices and purchasing options on an ongoing basis (Dudrow, 2001).

EMediator, from MediaDNA, controls how digital content is distributed and reproduced. End-users must download a plug-in in order to view protected content. Even with the downloaded plug-in, various levels of access to protected media can be set—viewing but not printing of images, set amounts of time for viewing content, or set number of times for printing content. End-users are prevented from sharing their purchased content with others (Dudrow, 2001).

Reciprocal, Inc. provides an end-to-end DRM solution by integrating technology from ContentGuard, Adobe, IBM, InterTrust, Microsoft, and Preview Systems. Content providers can choose the platform that best suits their business (Russ, 2001). The company provides digital clearinghouse and back-office services for many different industries.

Instead of securing content through encryption, the Copyright Clearance Center, in Danvers, Massachusetts, installs transaction engines on publishers' web sites that take orders for secondary use and reuse. Legal licenses for the content on a publisher's web page can be obtained within thirty seconds by a repeat user and within three minutes by a first-time user. The Boston Globe, the New York Times Online, the Wall Street Journal Online, and Barron's Online have all signed up for the CCC's service (Pack, 2001).

\section{DRM Challenges and Uncertainties}

Skepticism abounds about the effectiveness of DRM, as well as criticism of the restrictions it will place on end-users.

"DRM technologies may seem to be good news for content owners, be they record companies, movie studies, news organizations, or online publications. However, the inevitable consequence of the implementation of DRM technologies is inconvenience and needless restrictions for users of digital media and the Net" (Amis, 2001).

Andreas Pfeiffer, editor in chief of the Pfeiffer Report on Emerging Trends and Technologies pointed out what he calls DRM's "hidden dangers" (Pfeiffer, 2001). He is concerned that content providers are disregarding the potential side effects of copyright protection systems. He reminds content providers that "customers come first" and that, with its focus on illegal use of digital content, DRM ignores the needs of the lawful customer. "The first concern of any DRM solution should be to make sure that the intended user of the content doesn't experience any constraint on his legitimate use of the content he has acquired. The customer expects to be king-even in a digital world. Any system that doesn't offer the customer this basic consideration is doomed, "he said. Pfeiffer pointed out how software publishers gave up trying to provide copy protection for software, because users hated it and hackers could not be stopped from pirating it. Hardware copy protection is acceptable only to users of specialized programs for professionals. He mentioned the key-disk copy-protection scheme that Quark, Inc. originally used when it introduced Xpress in 1987, but which backfired with users and subsequently caused Quark, Inc. to have to release unprotected software (Pfeiffer, 2001).

According to Ranjit Singh, president of ContentGuard, many companies are putting DRM solutions on hold as they tackle issues related to pricing and distribution, as well as the need to hide the complexity of protection technologies from users. Users need to be able to buy the content they want "without needing special viewers or downloads and without putting the user through hoops," Singh said (McGarvey, 2001). 
Not everyone in the digital content industry agrees that DRM is the way to ensure the growth of digital content providers. At the Text One Zero digital book publishing conference, in May, 2001, Jim Griffin, CEO of Cherry Lane Digital, digital music delivery firm, argued that "it's not about controlling products, but growing your audience. Persuasion works better than coercion. We make more money when our content is out of our control" (Reid, 2001). Other conference participants pointed out flaws and the unconstitutionality of the DMCA, insisting that allowing digital content to be easily passed between consumers is the best way to generate interest and increase revenues.

Andy Gore, editor in chief for Macworld, said that his company's aim is to make Macworld's articles easily available and sharable, in order to reach more potential subscribers of the magazine (Jenkins, 2000). He feels that most customers would be alienated by pay-per-view models or other obstacles to easy access to online content. End-users are used to having online content free, and they don't value electronic content as much as hardcopy, because it has been free for so long. According to Gore, pay-per-view setups would only work for "highly vertical, competition-free markets" (Jenkins, 2000).

As companies adopt DRM solutions, they must keep in mind that digital content produces value only when it moves from the content creator to the end-user. For this reason, it is of utmost importance to use security hardware or software that does not interfere with a paying customer's easy, quick access to company's online content (Paraszczak, 2001).

Mark Schlack is vice president and editorial director of Itworld.com, which electronically publishes articles from sources such as Computerworld, CIO, Infoworld, NetworkWorld. All of the content on Itworld'com's web site is free of charge, and the company gets a boost in magazine subscriptions by allowing readers to share articles with others. Adopting DRM would cause Itworld.com to lose revenues from subscriptions. Schlack feels that digital rights management is more appropriate for business-to-business transactions and communications (Jenkins, 2000).

Publishers and content providers are eager to show their investors and shareholders that online publishing will result in revenue flows and profit margins. However, they still need to learn a lot about user tolerance and user behavior. "The challenge to the infant DRM industry is as hard to accomplish as it is easy to write - bridge the value chain between providers and users of information in such a way that the former think they have a just return and the latter think they have a fair deal" (Worlock, 2001).

Other concerns about DRM come from end-users themselves, who fear invasions of privacy as a result of third-party clearinghouses' collection of costumer information, such as when a customer plays an online game and the specific game modules the customer uses. Civil libertarians are concerned by the new cyberspace boundaries DRM could create by restricting the flow of information. Legal experts fear the control over information that will be given over to copyrighters, at the expense of consumers like librarians and scientists, who attempt to "deal fairly with intellectual property." (The Economist, 1999). Lawrence Lessig, of Harvard Law School, fears that software code could eventually replace legal code. He urges governments to consider protecting the consumers of intellectual property by limiting the capabilities of digital rights management systems. Lessig remarked that, instead of being taught about copyright, students may learn about copyduty, which he defines as "the legal obligation of copyright holders to provide public access." (The Economist, 1999).

According to Forrester Research, the publishing industry could lose up to $\$ 1.5$ billion from online piracy by 2005 (Peek, 2000). So far, copyright protection possible with DRM is still not completely hacker proof, and companies must be ready to spend a lot on catching violators and reach a balance where the costs of enforcing the copyright don't exceed the cost of lost revenues in question. Kenneth Richieri, general counsel at The New York Times worries that "the biggest threat to the copyright industry is the growth of a worldwide generation that really doesn't understand or respect copyright." (Peek, 2000). 
Issues and Opportunities in Digital Rights Management

Companies wishing to implement DRM are advised to seek the expertise of outside consultants and should plan on from three to twelve months to implement and integrate DRM (Russ, 2001). In seeking a DRM provider, companies should be sure to consider stability of the provider, its reputation among the leaders in the DRM industry, and the recommendations of previous users (Noakes-Fry, 2000). In order to ensure that a DRM solution will fit business needs, those seeking to adopt DRM should keep several points in mind: the types of content which need to be controlled, the value of the content (to both provider and recipients) vs. the cost of protecting it, the life cycle of the content to be controlled, and the specific set of rights to be controlled for each content type. Other important considerations include any technology limitations in distributor/consumer hardware or software that might impede the DRM solution's functioning on playback devices, the assumed level of trust with recipients, and the amount of solution transparency desired (Noakes-Fry, 2000).

\section{The Future of DRM}

According to Eric Scheirer, a media analyst at Forrester Research, "the types of companies that will be left are those that have successfully tied together their DRM technology with a much broader, integrated, content-management solution." (Pack, 2001).

Management of intellectual property rights is one of the critical success factors for companies hoping to succeed at eBusiness, according to a study at the University of California at Irvine (Vigoroso, 2001). A company's business plan must include digital rights management which considers the pricing of content, and the marketing value of collecting information about consumers that cannot be gathered through indirect retail distribution. (Meta Group, 2001).

Future DRM solutions will have to protect digital content, but also ensure that everyone in the creation, production, and distribution process gets paid fairly for use of the content. MetTrust Utility from InterTrust, for example, provides an end-to-end DRM solution by tracking payments from the online creditcard transaction to the royalty checks deposited in the author or artist's account (Adobe Systems Incorporated, 2001).

DRM use for the protection of business-to-business transactions is eventually expected to become DRM's largest market. By providing contract rights management, financial clearinghouse services, and tamperproofing, DRM will give businesses confidence in the confidentiality, security, and authenticity of electronic transactions and contracts (Maclachan, 2001).

In the future, DRMs will combine software and hardware access mechanisms, tying access rights directly to computer CPUs, hard drives, or other storage media, Publishers will be able to control who is reading their information and on what device. This will provide a needed high level of protection for legal documents or proprietary market research, where illegal copying and sharing could result in substantial damages (Adobe Systems Incorporated, 2001).

"In the future, DRM will be part of every digital environment," Shamroon added. "It will be part of the OS, part of the portable device, part of the server - it will be part of the computer" (Sanborn, 2000).

\section{Conclusion}

In the wake of the Digital Millennium Copyright Act, of 1998, Digital Rights Management systems are beginning to provide copyright protection for digital content which magazine and book publishers, music companies, software and game producers, and business-to-business participants place online. Creators and providers of digital content are now increasingly able to control end users' use of, and accessibility to, their products and stand to gain huge profits from this capability. However, as DRM technologies evolve and develop, so does end user concern about restrictions to their access to, and use of, information. The 
DRM industry will have to provide a balance between fair compensation for the creators of digital content and the rights of end-users to access and use the information they need.

\section{References}

Adobe Systems Incorporated. (2001). How DRM Works. Retrieved October, 2001 from hitp./Www.adobe.co.uk/epaper/featurestarm/howdmworks.hmm

Amis, D. (2001, April 8). Digital Rights Management Revisited. Internet Freedom. Retrieved October, 2001 from hitp://www.netfreedom.org/news.asp.item=152.hm!

ContentGuard. (2000). XrML White Paper. Retrieved October, 2001 from tttp://www.xrml.org/white_paper.htmI

Convergent Information Systems Division, National Institute of Standards and Technology. (2001, May 8). Digital Rights Management. Retrieved October, 2001 from 1 ttp://www.itl.nist.gov/div895/drmmain.htmm

Dudrow, A. (2000, September 1). Seybold: Digital Rights Management is All the Buzz. Creativepro.com. Retrieved October, 2001 from nttp://www.creativepro.com/story/feature/8433.htm

Duhl, J. (2001, June). The DRM landscape: Technologies, Vendors, and Markets. IDC\#24891. Retrieved October, 2001 from http://www.itresearch.com/alfatst4.nsi/unitabsx/W24891?openDocument\&q=24891+++++

The Economist. (1999, July 17). Science and Technology: Digital Rights and Wrongs. Retrieved October, 2001 from http://proquest.umi.com/pqdweb?Did=000000043275589\&Fmt=3\&Deli=1\&Mid=1\&Idx

Jenkins, C. (2000, September 1). New Protection against Online Pirates. Folio: The Magazine for Magazine Management. Re-

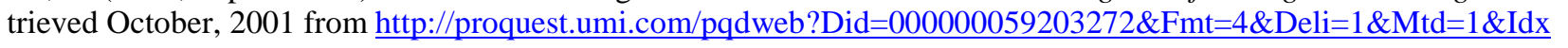

Kontzer, T. (2001, February 13). Napster Ruling Portends Digital Rights Revolution. Internetweek. Retrieved October, 2001 from ttp://Www.internetweek.com/story/INW2001021350003

Maclachlan, M. (2001, September 20). Time Is Coming for Digital Rights Management. IDC Ebusiness Trends Newsletter.

McGarvey, R. (2001, January/February). Digital Rights Management. Technology Review. Retrieved October, 2001 from http://proquest.umi.com/Did=000000065898914\&Fmt=4\&deli=1\&Mtd=1\&1dx

Meta Group. (2001, January 22). Commentary: Digital Rights Belong in Business Plan. CNET News.com Tech News First. Retrieved October, 2001 from ttp://news.cnet.com/news/0-1005-201-4562201-0.htm1

Noakes-Fry, K. (2000, October 16). Content Protection through Digital Rights Management (DRM): Perspective. Gartner Group. DPRO-93479.

O’Brien, P. (1999, April). Understanding Copyright Risks. Security Management. Retrieved October, 2001 from hittp://proquest.umi.com/pqdweb?Did=000000040526844\&Fmt=3\&deli=1\&Mtd=I\&Idx

O’Leary, M. (2001, February). DRM Emerging as Must-Have Copyright Solution. EContent. Retrieved October, 2001 from http://www.econtentmag.net/Magazine/Profiles/oleary2 01.html

Oliva, R. \& Prabakar, S. (1999, Spring). Copyright Perils Can Lurk on the Business Web. Marketing Management. Retrieved October, 2001 from htp.//proquest.umi.com/pqdweb?:Did=000000040558525\&Fmt=4\&Deli=1\&Mid=1\&Idx

Pack, T. (2001, May). Digital Rights Management: Can Technology Provide Long-Term Solutions? Econtent. Retrieved October, 2001 from nttp:t/ontineinc.com/articlestecontent/packsa_01.numm

Paraszczak, J. (2001, October 13). The Future of Digital Rights Management. The newnewstrategy. Retrieved October, 2001 from fltp:/twww.thenewnewstrategy.com/paget103.hmtm

Peek, R. (2000, November). The Digital Rights Management Dilemma. Information Today. Retrieved October, 2001 from http://proquest.umi.com/pqdweb?Did=000000063610/15\&Fmt=3\&Del1=1\&Mtd=1\&Idx

Pfeiffer, A. (2001, February 12). Digital Rights Management's Hidden Dangers. The Pfeiffer Report on Emerging Trends and Technologies Special to ZDNet. Retrieved October, 2001 from http://www.Zdnet.com/Zdnn/stories/comment/0,5859,2684435,00.htm

Reid, C. (2001, May 28). Schroeder Defends Need for Digital Rights Management. Publishers Weekly. Retrieved October, 2001 from http://proquest.umi.com/pqdweb?Did=000000073496957\&Fmt=3\&Deli=1\&Mtd=1\&Idx

Russ, A. (2001, July 26). Digital Rights Management Overview. SANS Institute Information Security Reading Room. Retrieved October, 2001 from nttp://www.sans.org/intosecFAQ/securitybasics/rights.htmm 
Issues and Opportunities in Digital Rights Management

Sanborn, S. (2000, June 19). Protecting Intellectual Property on the Web. InfoWorld. Retrieved October, 2001 from

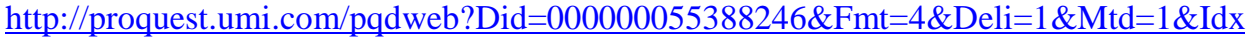

TechTarget. Digital Rights Management. Retrieved October, 2001 from

http://searchsystemsmanagement.techtarget.com/sDefinition/0"sid20_gci493373,00.html

ViaPay. (2000, November). Worth. Advertisement.

Vigoroso, M. W. (2001, July 20). Study: Winning at E-Commerce Requires Evolved Management Style. E-Commerce Times. Retrieved October, 2001 from 1 1tp://www.ecommercetimes.com/perl/printer/12150.htm/

Worlock, D. (2001, June). The Subtle Art of DRM. Information World Review. Retrieved October, 2001 from http://proquest.umi.com/pqdweb?Did=000000074060216\&Fmt=3\&Deli=1\&NId=1\&ाdx

\section{Biographies}

Abbas Foroughi is a professor of computer information systems at the University of Southern Indiana. He holds a Ph.D. in Business Administration from the Kelley School of Business at Indiana University. His research interests include Negotiation Support Systems, Decision Support Systems, Internet Security, XBRL, E-Business, Online Distance Education, and Curriculum Development. He has works published in Decision Support Systems: The International Journal, Group Decision and Negotiation, The Journal of Applied Research, the Journal of Computer Information Systems, The International Journal of Purchasing and Materials Management, The International Journal of the Theoretical and Practical Aspects of Management, The National Public Accountant Journal, The Financial Post, and The Review of Business Information Systems.

Marvin Albin is a professor of computer information systems and chair of the Department of Information Systems at the University of Southern Indiana. His doctorate is from Arizona State University. His research interests are web content management, the MIS/CIS job market for graduates, and management of the IS function. His writings have been published in the Journal of Computer Information Systems, ISECON Proceedings, and the Association for the Advancement of Information Systems Proceedings.

Sharlett Gillard is an associate professor of computer information systems at the University of Southern Indiana. She has an Ed.D. in College Teaching from the University of North Texas. Dr. Gillard's research interests include project management and curricular issues in CIS and have resulted in publications in Program Manager, Journal of Accounting and Finance Research, and Theoretical and Practical Aspects of Management. 